\title{
PROFILE OF PATIENTS WHO SEEK THE BARIATRIC SURGERY
}

Perfil de pacientes que buscam a cirurgia bariátrica

Paola Turchiello da SILVA, Luciana Dapieve PATIAS, Glauco da Costa ALVAREZ,

Vanessa Ramos KIRSTEN, Elisângela COLPO, Cristina Machado Bragança de MORAES

From the Clínica de Cirurgia da Obesidade e do Aparelho Digestivo de Santa Maria (Surgery Clinic of Obesity and Digestive System of Santa Maria), Santa Maria, RS, Brazil.

HEADINGS - Obesity. Bariatric surgery. Epidemiology.
ABSTRACT - Background: Nowadays obesity is a chronic disease considered one of the greatest problems in public healthy. Showing to be effective in a short and long term, the bariatric surgery has emerged as an optional treatment for morbid obesity. Aim: Identify the profile of patients seeking bariatric surgery. Methods: Were interviewed 100 patients in preoperative nutritional monitoring of bariatric surgery. The study was conducted by applying a questionnaire prepared according to the research objectives. Results: From the individuals that were seeking bariatric surgery, $78 \%$ were female, $62 \%$ were married and $69 \%$ reported physical activity. The average age of those surveyed was $37 \pm 10.83$ years and mean body mass index (BMI) was $43.51 \pm 6.25 \mathrm{~kg} / \mathrm{m}^{2}$. The comorbidity more prevalent in this group was high blood pressure (51\%). In previous treatments for weight reduction, $92 \%$ have already done hypocaloric diet followed by anorectic drug ( $83 \%)$. The success of these treatments was reported by $92 \%$ of patients; however, the weight lost was recovered in less than one year of $75 \%$. Patients with diabetes mellitus and dyslipidemia had higher $\mathrm{BMI}$ values. The patients with comorbidities showed lower levels of BMI. Conclusion: The profile of patients who sought surgical treatment for their obesity were predominantly women with a family background of obesity and obesity-related comorbidities, especially hypertension and diabetes mellitus.

\section{Correspondence:}

Felipe José Fernández Coimbra

E-mail: coimbra.felipe@uol.com.br

Financial source: none

Conflicts of interest: none

Received for publication: 23/04/2015 Accepted for publication: 27/07/2015

DESCRITORES - Obesidade. Cirurgia Bariátrica. Epidemiologia.
RESUMO - Racional: A obesidade é doença crônica considerada atualmente um dos maiores problemas de saúde pública. Mostrando-se eficaz em curto e longo prazo a cirurgia bariátrica surgiu como opção de tratamento para a obesidade grau III. Objetivo: Identificar o perfil dos pacientes que procuram a cirurgia bariátrica. Métodos: Foram entrevistados 100 pacientes em acompanhamento nutricional pré-operatório de cirurgia bariátrica. $\mathrm{O}$ estudo foi realizado através da aplicação de um questionário elaborado de acordo com os objetivos da pesquisa. Resultados: Dos indivíduos que buscaram a cirurgia bariátrica, $78 \%$ eram do sexo feminino, $62 \%$ casados e $69 \%$ dos entrevistados afirmaram praticar atividade física. A média de idade dos indivíduos pesquisados foi de $37 \pm 10,83$ anos e a média de IMC foi de $43,51 \pm 6,25 \mathrm{~kg} / \mathrm{m}^{2}$. A comorbidade que mais prevaleceu no grupo pesquisado foi a hipertensão arterial (51\%). Dos tratamentos prévios para redução de peso, $92 \%$ já realizou dieta hipocalórica seguido de medicamento anorexígeno (83\%). O sucesso destes tratamentos foi relatado por $92 \%$ dos pacientes; porém, o peso perdido foi recuperado em menos de um ano por $75 \%$. Ao associarem-se as comorbidades com o IMC, encontrou-se diferença significativa entre os pacientes com e sem diabete melito, assim como os com e sem dislipidemia. Os pacientes que apresentavam comorbidades mostraram menores níveis de IMC. Conclusão: O perfil dos pacientes que buscaram correção cirúrgica para sua obesidade eram predominantemente mulheres, com histórico familiar de obesidade, com média de idade de 37 anos e com comorbidades relacionadas à obesidade, com destaque para hipertensão arterial e diabete melito.

INTRODUCTION

$\mathrm{N}$ owadays, obesity is considered one of the biggest problems in public health ${ }^{4}$. Seen as a worldwide epidemic, it defined as the accumulation of fat tissue in the organism, result of the energy intake that is over the expenditure energy ${ }^{11}$.

According to the Pesquisa de Orçamentos Familiares de 2008-200910, 50\% of men and $48 \%$ of women were overweight, from these group $12,5 \%$ of men and $16,9 \%$ of women were obese.

The risk of medical comorbidity is directly associated to the Body Mass Index $(\mathrm{BMI})$, the abdominal fat or visceral is an independent risk factor to diseases related to overweight and obesity ${ }^{20}$.

Treatments used to treat morbid obese patients, pharmacologic and dietetic, have low prevalence, mainly because there is not a changing in life style. The success, 
depends of the constantly vigilance of food intake - beyond factors as familiar and social support, self monitoring and most of the time, they are no well performed, creating disappointment among patients ${ }^{7}$.

Surgery treatments have been efficient in a short and long term, by weight loss and solving the medical comorbidity for treatments of grade II obesity ${ }^{16}$. Some requirements have to be followed to indicate the surgery, as BMI equal or more than $40 \mathrm{~kg} / \mathrm{m}^{2}$ without medical comorbidity associated or more than $35 \mathrm{~kg} / \mathrm{m}^{2}$ with medical comorbidity ${ }^{3}$.

This study is aimed to identify the patient's profile that seek the bariatric surgery.

\section{METHOD}

This study has been reviewed and approved by the Centro Universitário Franciscano Internal Review Board (No. 235.073) and informed consent was obtained from all participants.

Were interviewed 100 patients at the Surgery Clinic of Obesity and Digestive System of Santa Maria, Santa Maria, RS, Brazil during the nutritional assessment of the pre-bariatric surgery in the period of April to May, 2013.

The study was conducted through a questionnaire with personal information (gender, age, marital status, profession) and specific information about their clinic obesity history, physical activity, alcohol intake, smoking and others method to weight loss previously to the bariatric surgery. It was also asked the motivation to perform the bariatric surgery as a treatment and what would be the main goal to their weight loss

Data were analyzed in the SPSS version 18.0 and presented as a simple descriptive statistic (mean \pm SD and percentage). Comparison between the means was done using t-Student test.

\section{RESULTS}

From the subjects submitted to bariatric surgery, the sample was characterized mainly by women $(78 \%)$, married (62\%), physically active (69\%) and low prevalence of smokers (11\%) and alcohol drinkers (10\%) (Table 1).

TABLE 1 - Demographic profile, alcohol intake, smoking and physical activity practice in subjects that seek the bariatric surgery (2013)

\begin{tabular}{|c|c|c|c|c|c|c|c|c|c|c|}
\hline & \multicolumn{2}{|c|}{ Gender } & \multicolumn{2}{|c|}{$\begin{array}{l}\text { Marital } \\
\text { Status }\end{array}$} & \multicolumn{2}{|c|}{ Smokin } & \multicolumn{2}{|c|}{$\begin{array}{l}\text { Alchoholic } \\
\text { Beberage }\end{array}$} & \multicolumn{2}{|c|}{$\begin{array}{l}\text { Physical } \\
\text { Activity } \\
\text { Practice }\end{array}$} \\
\hline & M & $\mathrm{F}$ & & & & & & & Yes & No \\
\hline$\%$ & 22 & 78 & 38 & 62 & 11 & 89 & 10 & 90 & 69 & 31 \\
\hline & (22) & (78) & (38) & (62) & (11) & (89) & (10) & (90) & (69) & (3) \\
\hline
\end{tabular}

The average age of the subject analyzed was of $37.8 \pm 10.8$ years old (minimum age of 17 and maximum 68 years old). Regarding the medical comorbidity $24 \%$ did not report, $39 \%$ reported between one and two and $37 \%$ reported three. Among them, the most frequent were hypertension (51\%), apnea (33\%) and diabetes (27\%) (Figure 1).

Regarding the nutritional status classification, $81 \%$ were classified as obesity grade III. Almost all subjects (83\%), reported an obesity family background, $54 \%$ were overweight since childhood (Table 2).

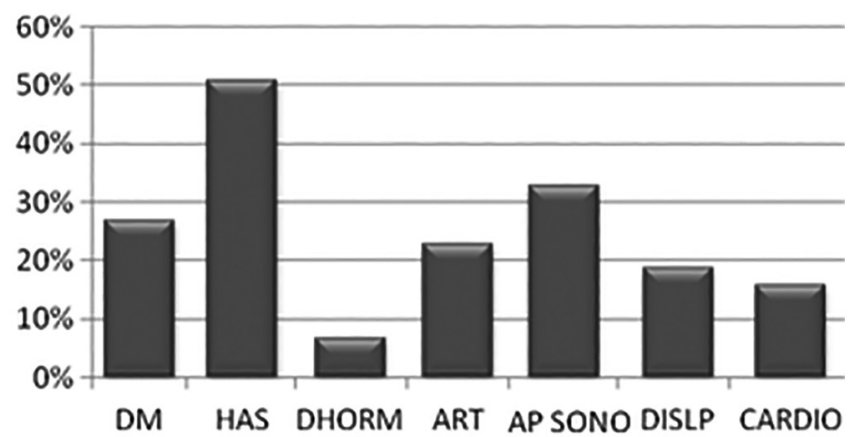

DM=diabetes; $\mathrm{HTN}=$ hypertension; $\mathrm{ENDOCR}=$ endocrine disturbances; $\mathrm{ARTH}=$ arthritis; $\mathrm{APNEA}=$ sleep apnea; $\mathrm{DYSLP}=$ dyslipidemia; $\mathrm{CAD}=$ cardiovascular diseases

FIGURE 1 - Prevalence of medical comorbidity associated to obesity in patients submitted to bariatric surgery, Santa Maria-RS (2013)

TABLE 2 - Nutritional status, family background and childhood overweight

\begin{tabular}{|c|c|c|c|c|c|c|}
\hline & \multicolumn{2}{c}{ Nutritional status } & \multicolumn{3}{c|}{ Family background } & \multicolumn{3}{c|}{ Overweight in childhood } \\
\hline & Obes II & Obes III & Yes & No & Yes & No \\
\hline \% & 19 & 81 & 83 & 17 & 54 & 46 \\
\hline (n) & $(19)$ & $(81)$ & $(83)$ & $(17)$ & $(54)$ & $(46)$ \\
\hline
\end{tabular}

The average BMI was $43.51 \pm 6.25 \mathrm{~kg} / \mathrm{m}^{2}$, being the lowest value found $35 \mathrm{~kg} / \mathrm{m}^{2}$ and the highest $85.78 \mathrm{~kg} / \mathrm{m}^{2}$.

When the subjects were asked regarding the use of others previous treatment to the weight loss, $92 \%$ answered that they have already done hypocaloric diet and $53 \%$ the fad diet as a treatment. The use of appetite suppressants were appointed by a high number of subjects (83\%) (Figure 2).

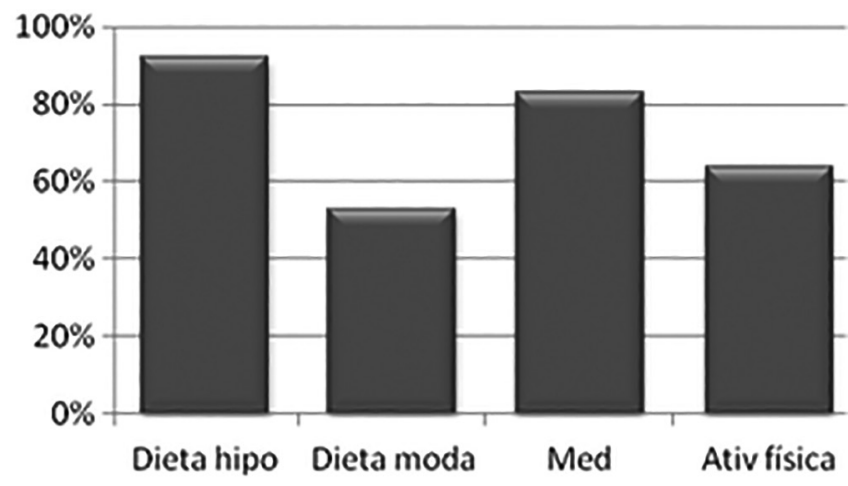

Note: Hypo diet= Hypocaloric Diet; Fad Diet= Fad Diet; Med= Medicines; Physic Act $=$ Physical Activity

FIGURE 2 - Previous methods to weight loss

The success of the treatments highlighted in the picture 2 was reported by $92 \%$ of the patients; however the weight was regained in less than one year by $75 \%$ of the interviewees.

Concerning the healthcare professional's supervision to weight loss treatment, $24 \%$ have been supervised by nutritionists; $20 \%$ by a physician; $42 \%$ by both; and $14 \%$ without professional supervision.

When comparing the BMI with gender and marital status, men have showed a higher BMI than women, as well as it was higher in single individuals $(p<0,01)$. 
TABLE 3 - Relation between BMI, gender and marital status

\begin{tabular}{|c|c|c|c|c|c|c|}
\hline & \multicolumn{3}{c}{ BMI vs Gender } & \multicolumn{3}{c|}{ BMI vs Marital status } \\
\hline & Female & Male & $p$ & Single & Married & $p$ \\
\hline $\begin{array}{c}\text { BMl } \\
\left(\mathrm{kg} / \mathrm{m}^{2}\right)\end{array}$ & $42.04 \pm 4.45$ & $48.04 \pm 9.82$ & $<0,01$ & $44.12 \pm 5.1$ & $42.89 \pm 7.21$ & $<0,01$ \\
\hline
\end{tabular}

Results are expressed as mean $\pm \mathrm{SD}\left({ }^{\star}\right)$ t-test

When associate BMI with medical comorbidities, it was verified that patients without diabetes and dyslipidemia have showed lower average values to the BMI $(p<0,05)$ (Table 4$)$.

TABLE 4 - Average BMI value comparison with medical comorbidities presence

\begin{tabular}{|c|c|c|c|}
\hline Medical comorbidities & & BMI $\left(\mathrm{kg} / \mathrm{m}^{2}\right) \pm S D$ & p \\
\hline \multirow{2}{*}{ Diabetes } & Yes & $41.25 \pm 5.51$ & \multirow{2}{*}{0.04} \\
\hline & No & $44.14 \pm 6.68$ & \\
\hline \multirow{2}{*}{ Hypertension } & Yes & $43.44 \pm 7.57$ & \multirow{2}{*}{0.89} \\
\hline & No & $43.26 \pm 5.2$ & \\
\hline \multirow{2}{*}{ Apnea } & Yes & $44.04 \pm 9.26$ & \multirow{2}{*}{0.45} \\
\hline & No & $43.02 \pm 4.61$ & \\
\hline \multirow{2}{*}{ Hormonal diseases } & Yes & $41.22 \pm 4.13$ & \multirow{2}{*}{0.36} \\
\hline & No & $43.51 \pm 6.62$ & \\
\hline \multirow{2}{*}{ Arthritis } & Yes & $42.55 \pm 4.40$ & \multirow{2}{*}{0.50} \\
\hline & No & $43.59 \pm 6.99$ & \\
\hline \multirow{2}{*}{ Dyslipidemia } & Yes & $39.98 \pm 5.59$ & \multirow{2}{*}{0.01} \\
\hline & No & $44.15 \pm 6.46$ & \\
\hline \multirow{2}{*}{ Cardio } & Yes & $44.01 \pm 12.42$ & \multirow{2}{*}{0.66} \\
\hline & No & $43.23 \pm 4.71$ & \\
\hline
\end{tabular}

The factors that most influenced in the weight gain were: high energy intake (76\%), physical inactivity (63\%), family background (50\%) and binge eating (63\%). The most part of the sample pointed more than one factor (Figure 3 ).

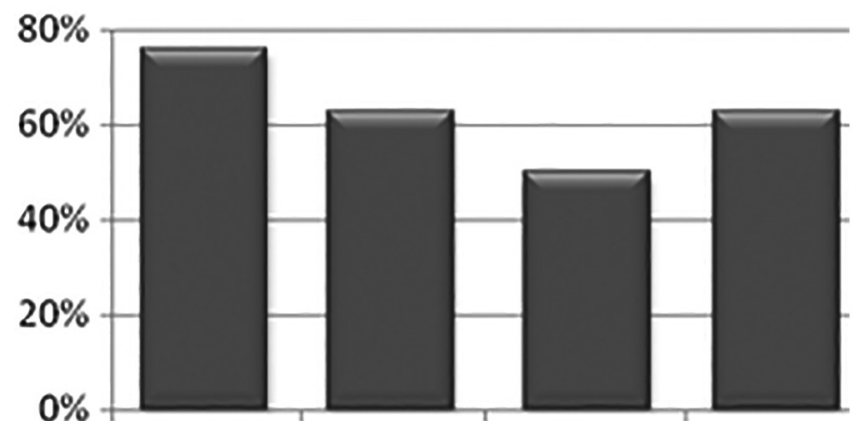

$\mathrm{HEI}=$ high energy intake; $\mathrm{PHYSINACT}=$ physical inactivity; $\mathrm{FAM}=$ family background $\mathrm{BE}=$ binge eating

\section{FIGURE 3 - Factors associated to overweight}

The main reasons that motivated the patients to be submitted to bariatric surgery as a treatment, $49 \%$ pointed the failure in the previous treatments, 39\% medical comorbidities, $12 \%$ by the treatment efficiency and facility in losing weight.

The main objective to be submitted to bariatric surgery, $87 \%$ reported the improvement in the life quality; $82 \%$ the improvement in their health; $34 \%$ the beauty factor; and $15 \%$ to be accepted in society.

\section{DISCUSSION}

The main findings of this study demonstrate that before surgery, the patients were mainly women, with high prevalence of medical comorbidities, showing a family obesity history and the performance of previous dietetics interventions without any success. Regarding the age, there is a trend to this type of surgery, it has increasingly been performed in young patients with a high level of obesity, as also highlighted by others authors ${ }^{19,8}$.

According to Craig and Trusweel, the marriage can influence the weight gain, mainly between women. The reasons could be the decrease of energy expenditure and alteration of eating habits 5 . In this study, differently, the BMI has been higher in single patients, and men had higher BMI than women. These results can be justified by the social life of single people associated to habits as high alcohol intake and a great number of out-of-home-eating.

Regarding the medical comorbidities, $76 \%$ pointed some disease, data higher than the found by Cambi et al., which only $40 \%$ of patients had it ${ }^{2}$. According to the World Health Organization, as higher as the value of $\mathrm{BMI}$, there is an increase the risk of medical comorbidities, predominating hypertension, followed by apnea and diabetes ${ }^{15}$. Lichtblau et al. found different results with prevalence of respiratory problems (70\%) and osteoarticular $(63,3 \%)$, followed by hypertension $(53,3 \%)^{12}$.

Concerning the smoking and drinking, it has been found a low consumption that is considered satisfactory according to Still, Benotti, Wood et al. the alcohol dependency or illicit drugs is contraindicated to the bariatric surgery ${ }^{17}$.

In this study the high number of physical activity practitioners was probably because of the multidisciplinary group supervision in the preoperative phase ${ }^{13}$.

Although the pharmacological treatment helps the weight loss in patients, the effectiveness and medicine safety for longer than two years is not completely established. Success in previous treatments before the surgery, was highlighted by $92 \%$ of patients; however, the weight was regained in less than one year by $75 \%$ of the patients.

The National Institute of Health, estimate that almost $80 \%$ of people that lose weight tend to regain it, and $1 / 3$ to $2 / 3$ of this recovery occurs just in the first year after losing ${ }^{14}$.

The biggest part of the subjects studied has reported a family obesity history and overweight since childhood, supporting the data found by Porto et al. ${ }^{15}$. It is highly probable that the polygenic inheritance is a determinant factor. The risk of being obese in childhood, can increase when parents are also obese. When none of the parents are obese, the risk is of $9 \%$, however when one parent is obese, it increases to $50 \%$ and to $80 \%$ when both are obese ${ }^{18}$.

Most the causes of obesity are not easily identified. It is multifactorial and can be classified into two major contexts: exogenous, influenced by external factors of behavioral origin, dietary and environmental in $95 \%$ of cases, and endogenous, by genetic, neuropsychological, endocrinology and metabolism at $5 \%{ }^{6}$.

In a previous study it was demonstrated that binge eating is present in $27-47 \%$ patients that sought for the bariatric surgery to weight loss ${ }^{1}$.

Surgical treatment promotes the weight loss, improves metabolism and life quality, according to the main goal sought by the patients of this study that were submitted to bariatric surgery ${ }^{9}$.

\section{CONCLUSION}

The profile of patients who sought surgical treatment for their obesity were predominantly women with a family background of obesity and obesity-related comorbidities, especially hypertension and diabetes mellitus. 
REFERENCES

1. AzevedoAP,SantosCC, FonsecaDC. Transtorno da compulsãoalimentar periódica. Rev Psiquiatr Clin. 2004; 31(4):170-2.

2. Cambi MPC, Michels G, Marchesini JB. Aspectos nutricionais e de qualidade de vida em pacientes submetidos à cirurgia bariátrica. Rev Bras Nutr Clin. 2003; 18(8): 8-15.

3. Carreiro, DM; Zilberstein B. Mitos e Realidades sobre Obesidade e Cirurgia Bariátrica. São Paulo: Metha, 2004.

4. Cintra IP, Oliveira $C L$, Fisberg M. Obesidade: tratamento e prevenção. Rev Nutr em Pauta 2001; 50: 11-17.

5. Craig PL, Truswell AS. Dynamics of food habits of newly married couples: weight and exercise patterns. Aust J Nutr Dietet 1990;47:42-6.

6. Damaso A, Guerra RLF, Botero JP, Prado WL. Etiologia da obesidade. In: DAMASO, A. Obesidade. Rio de Janeiro: Medsi, 2003;03-15.

7. Diretrizes Brasileiras de Obesidade. Assoociação Brasileira para o Estudo da Obesidade da Síndrome Metabólica. ABESO $3^{\mathrm{a}}$ ed. São Paulo, 2009/2010. [acesso em 13/09/2012]. Disponível em: http://www. abeso.org.br/pdf/diretrizes_brasileiras_obesidade_2009_2010_1.pdf.

8. Garrido AB, Gama-Rodrigues JJ, Waitzberg DL. Obesidade mórbida: tratamento cirúrgico.In:Waitzberg DL.Nutriçãooral, enteral eparenteral na prática clínica. São Paula: Atheneu, 2000; 1041-1047.

9. Garrido AB. Cirurgia da Obesidade. São Paulo: Atheneu, 2004.

10. Instituto Brasileiro de Geografia e Estatística. Pesquisa de Orçamentos Familiares 2008-2009. [acesso em 13/09/2012]. Disponível em: http:// www.ibge.gov.br/home/presidencia/noticias/noticia_visualizada. php?id_noticia $=16998$ \&id_pagina $=1$.

11. JamesPT.Obesity:TheWorldwideEpidemic.Clindermatol2004;22(4):276280.
12. Lichtblau MEF, Souza YSS. Critérios Adotados para a realização da Cirurgia Bariátrica nos Hospitais de Florianópolis/SC. 2006. Monografia (Especialização em Obesidade e Emagrecimento), Universidade Veiga de Almeida, Santa Catarina.

13. Mendes MJFL, Alves JGB, Alves AV, Siqueira PP, Freire EFC. Associação de fatores de risco para doenças cardiovasculares em adolescentes e seus pais. Rev Bras Saúde Matern Infant 2006;6: 49-54.

14. NIH, N. I. o. H., Institute, N. H. L. a. B., \& Obesity, N. A. A. f. t. S. o. $(2000$, outubro). The Pratical Guide: Identification, Evaluation, and Treatment ofOverweight and Obesity in Adults. NIH Publication Number 00-4084.

15. Porto MCV. et al. Perfil do obeso classe Ill do ambulatório de obesidade de um hospital universitário de salvador, Bahia. Arq Bras Endocrinol Metab 2002; 46:6.

16. Sjostrom $L$ et al. Lifestyle, diabetes, and cardiovascular risk factors 10 years after bariatric surgery. N Engl J Med 2004;351(26):2683-86.

17. Still CD, Benotti P, Wood CG, et al. Outcomes of pre-operative weight loss in high-risk patients undergoing gastric bypass surgery. Arch Surg 2007; 142:994-8.

18. Van den Bree MB, Eaves LJ, Dwyer JT. Genetic and environmental influences on eating patterns of twins aged $>/=50 \mathrm{y}$. Am J Clin Nutr 1999;70:456-65.

19. Vargas CB, Moraes MB, Liberali R. Discrição do Padrão de Execução das Técnicas Fisioterapêuticas Propostas para Prevenção de Complicações Respiratórias em Pacientes que Realizaram Cirurgia Bariátrica no Centro de Obesidade e Síndrome Metabólica. Rev Bras Obes, Nutr Emagrecimento 2009;3(15)::251-259.

20. WyattSB, Winters KP, DubbertPM. Overweightand obesity: Prevalence, Consequences and Causes of a Growing Public Health problem. Am J Med Sci 2006;331(4):166-174. 